\title{
DNA-Based Toxicity Assay for Pesticides in the Environment
}

\author{
Ethelbert U. Ezeji1 , Ikechukwu N. E. Onwurah², Angela C. \\ Udebuani1
}

\author{
${ }^{1}$ Department of Biotechnology, Federal University of Technology, P.M.B. 1526 Owerri, Nigeria \\ ${ }^{2}$ Pollution Control and Biotechnology Unit, Department of Biochemistry University of Nigeria, Nsukka
}

\begin{abstract}
Increased use of domestic and agricultural pesticides has become a serious threat to the environment. Prolonged exposure to pesticides is capable of affecting the genetic integrity of humans and other animals. The aim of this study is to access the effect of dichlorvos (DDVP), a widely used pesticide in Nigeria, on the DNA of poultry birds (Gallus domestica). This study explored different special representation of treated groups using a three-patch matrix model incorporating dichlorvos contamination $(0.01,0.02$ and $0.4 \%)$. Exposure was carried out for ten weeks after which the birds were sacrificed and the liver was extracted. Thermal denaturation of the DNA from the exposed birds resulted in a significant reduction $(\mathrm{p}<0.01)$ in the DNA melting temperature from $87.2^{\circ} \mathrm{C}$ to $81.7^{\circ} \mathrm{C}$ while the GC/AT ratio was also significantly reduced $(\mathrm{p}<0.01)$ from 0.77 in the control to 0.42 in exposed birds respectively. Electrophoresis of isolated DNA in $0.8 \%$ agarose gels gave variations in band intensity between the control DNA sample and DNA from exposed birds. These variations in band intensity were more pronounced in the RAPD-PCR products amplified with OPE-01 primer, where there is complete disappearance of DNA bands in the birds exposed to $0.04 \%$ pesticide. Thus deletion of DNA segments of birds exposed to dichlorvos can be modelled as a molecular biomarker of genotoxicity. This may also suggest that insecticides are capable of impacting genotoxic effects on non-target populations with consistent, long-term use.
\end{abstract}

Keywords: Pesticides, genotoxicity, RAPD-PCR, melting temperature, DNA strand breaks. RUNNING TITLE: Genotoxic effect of dichlorvos pesticide on poultry birds.

\section{INTRODUCTION}

Pesticides are one of the most potentially harmful chemicals introduced into the environment. Although they have contributed considerably to human welfare, their adverse impacts on non-target organisms are significant (Hazarika and Das, 1998; John, 2007). Widespread use of pesticides in agriculture and domestic pest control has contributed to the pollution of the environment (Partanen et al. 1999). Bioaccumulation of pesticides in the food chain can lead to potentially adverse effects in humans and useful animals due to their apparent toxic effect. Some pesticides are highly persistent in nature, causing contamination of soil, ground and surface water (Wolfe et al. 1973; Frank et al. 1990). DNA is one of the most critical cellular targets for hazardous chemicals and wastes (Birnboin and Jevcak, 1981). Exposure to environmental xenobiotics, including pesticides, has the ability to cause DNA damage through the formation of strand breaks and DNAadducts. Many in vitro and in vivo studies, as well as epidemiological approaches, have demonstrated the ability of certain chemical pesticides to produce genetic effects including cancer and other chronic pathologies in humans (Bolognesi et al. 1981). A number of DNA based assays have been used for in vitro study of effects of pesticides. In this study DNA melting characteristics and random amplified polymorphic DNA (RAPD) were used to access the genotoxic effects of pesticide exposure.

\section{MATERIALS AND METHODS}

\section{Test Sample}

Dichlorvos (2,2 - dichlorovinyldimethyl phosphate) -DDVP, was purchased from an agrochemical shop in Owerri.
Formulation of Contaminated Poultry feeds
Commercially available poultry feed was contaminated by weighing out a definite amount of the feed and mixed with a graded percentage of the pesticide to give $0.01,0.02$ and $0.04 \%$ (w/v) contamination respectively. Feed for the control contained no pesticide

This article is published under the terms of the Creative Commons Attribution License 4.0 Author(s) retain the copyright of this article. Publication rights with Alkhaer Publications.

Published at: http://www.ijsciences.com/pub/issue/2016-07/

DOI: 10.18483/ijSci.1058; Online ISSN: 2305-3925; Print ISSN: 2410-4477 


\section{Experimental Animals}

Day old black pullets were obtained from Zartec Farms, Ibadan, Nigeria. The birds were brooded under appropriate conditions until they were seven weeks old. The seven weeks old pullets with an average weight of $557.5 \pm 9.5 \mathrm{~g}$ were divided into four groups containing 10 birds each and housed in poultry pens at the livestock unit of the Department of Animal Science and Technology, Federal University of Technology, Owerri, Nigeria. Three groups received a diet containing $0.01,0.02$ and 0.04 $\%$ dichlorvos respectively, while the control was fed on pesticide-free diet. The experiment lasted for a period of ten weeks.

\section{Isolation of liver DNA}

After ten weeks of exposure, two birds each were taken from each group and sacrificed by decapitation and the liver extirpated. Liver DNA was isolated using the method of Sambrook et al. 1989). The concentration of DNA was determined spectrophotometrically at O.D $260 \mathrm{~nm}$. Purity was determined based on A260/280 ratio.

Conc of DNA $=\mathrm{A} 260 \mathrm{x}$ dilution factor $\mathrm{x} 50 \mathrm{ug} / \mathrm{ml}$

Total yield $=$ Conc of DNA $x$ total purified sample volume

\section{Agarose gel electrophoresis of DNA}

The molecular pattern of the isolated DNA samples was analysed using Agarose gel electrophoresis. Molten agarose [0.8\%] gel (2.4 g of agarose in $300 \mathrm{ml}$ of Tris-acetate buffer) $+30 \mu$ of ethidium bromide was poured into a horizontal electrophoresis plate and allowed to set after which the electrophoresis buffer $(0.04 \mathrm{M}$ Tris-acetate, $0.002 \mathrm{M}$ EDTA, $\mathrm{pH}$ 8.0) was poured into the tank. Five microlitre $(5 \mu \mathrm{l})$ of gel loading buffer $(2.5 \mathrm{mg}$ bromophenol blue, $4 \mathrm{~g}$ sucrose, in $6 \mathrm{ml} 10 \mathrm{mM}$ Tris- $\mathrm{HCl}, \mathrm{pH} 8$ and $1 \mathrm{mM}$ EDTA) was added to each $25 \mu$ of DNA sample and carefully loaded into the wells. The gel was run at 3040 volt overnight and the ethidium bromide stained bands were observed and photographed using a UV transilluminator.

\section{Thermal denaturation of DNA}

Thermal denaturation of DNA was carried out by dissolving 10ml of DNA solution in $990 \mathrm{ml}$ of saline sodium citrate (SSC) buffer. The DNA solution was placed in a stoppered special thermal cell (A.H. Thomas Co. Philadelphia, PA. USA), and overlaid with mineral oil to prevent evaporation. The samples were incubated at $70^{\circ} \mathrm{C}, 75^{\circ} \mathrm{C}, 80^{\circ} \mathrm{C}, 90^{\circ} \mathrm{C}$ and $95^{\circ} \mathrm{C}$ for 30 minutes. The rate of temperature increase was controlled by a thermocouple type F4301 (Haake Berlin Karsruhe, Germany). The melting profile was generated by measuring absorbance at $260 \mathrm{~nm}$ every $0.5^{\circ} \mathrm{C}$. A graph of absorbance against temperature was plotted and the melting temperature $(\mathrm{Tm})$ was determined from the graph. The percentage GC $(\% \mathrm{GC})$ was calculated using the formular: $\% \mathrm{GC}=$ $\left(\mathrm{Tm}-70^{\circ} \mathrm{C}\right) \times 2.5$, where 2.5 is a constant.

\section{RAPD-PCR Analysis}

The RAPD PCR was carried out using 4 primer sets: OPA-02 (5'-TGCCGAGCTG-3'), OPB-06 (5' TGCTCTGCCC-3'), OPC-04 (5'-CCGCATCTAC$3^{\prime}$ ) and OPE-01 (5'- CCCAAGGTCC-3'). The RAPD protocol used was the one described by Ferrero et al. [5]. The PCR was performed in $25 \mu 1$ of a reaction mixture containing DNA (10-200 ng), 200 $\mu \mathrm{M}$ of each deoxynucleoside triphosphates (dNTP) (Promega), $2.5 \mathrm{mM} \mathrm{MgCl} 2$, 1X PCR Buffer, $20 \mu \mathrm{M}$ primer, 2.5 units of Taq DNA polymerase (Promega) and sterile distilled water. Thermal cycling was conducted in an Eppendorf Master Cycler Gradient for an initial denaturation at $94^{\circ} \mathrm{C}$ for 5 minutes followed by 40 amplification cycles of 1 minute at $94^{\circ} \mathrm{C} ; 1$ minute at $28^{\circ} \mathrm{C}$ and 1 minute at $72^{\circ} \mathrm{C}$. This was followed by a final extension step for 10 minutes at $72^{\circ} \mathrm{C}$. The amplification product was separated on $1 \%$ agarose gel electrophoresis and visualized by ethidium bromide staining. $1 \mathrm{~kb}$ DNA ladder was used as DNA molecular weight standard.

\section{Statistical Analysis}

The results were analyzed statistically using a one way analysis of variance (ANOVA). The results were expressed as mean \pm SEM. The means were separated using Turkey's test and considered different at $\mathrm{p}<0.01$ and $\mathrm{p}<0.05$.

\section{RESULTS}

The molecular pattern of isolated liver DNA in agarose gel shows that there were distinct bands for each DNA isolated from the different birds (Plate 1). The highest yield of DNA was observed with the birds fed on $0.04 \%$ pesticide contaminated diet (Table 1). All DNA samples isolated from the different liver tissues were found to be relatively pure as shown by their A260/A280 ratios. Generally a high quality DNA sample has an A260/A280 ratio between 1.7 and 2.0. There was significant reduction $(\mathrm{p}<0.01)$ in the DNA melting temperature from $87.2 \%$ in the control to $81.7 \%$ in birds exposed to the pesticide. The Guanine-cytosine/Adenine-Thymine (GC/AT) ratio was also significantly reduced $(\mathrm{p}<0.01)$ from 0.77 in the control to $0.42 \%$ in birds exposed to the pesticide (Table 2). Results of the RAPD-PCR analysis shows that there were variations in band intensity between the control DNA sample and those exposed to pesticide. Variations were particularly observed in the products amplified with OPA-02 (Plate 2), OPC-04 (Plate 3) and OPE-01 
(Plate 4). The DNA profile of the PCR product amplified with the primer OPE-01 also shows a disappearance of bands in the DNA of the birds fed on 0.02 and $0.04 \%$ pesticide contaminated diet (Plate 4).

\section{DISCUSSION}

Dichlorvos has been in widespread use as an insecticide for over 40 years, during which time its carcinogenicity and genotoxicity have been evaluated extensively (Booth et al. 2007). Molecular pattern of isolated DNA from the liver of birds exposed to dichlorvos reveals distinct bands on agarose gel. There was however no observable differences between the DNA bands of the control and those exposed to the pesticide. This suggests that analysis of DNA on agarose gel alone is not sensitive enough to reveal any significant damage caused by dichlorvos on the DNA of poultry birds. The melting temperature $\left(\mathrm{T}_{\mathrm{m}}\right)$ is defined as the temperature at which half of the DNA strands are in the double helical state and half are in the random coil states (Santalucia, 1998). The melting temperature depends on both the length of the molecule, and the specific nucleotide sequence composition of that molecule. $\mathrm{T}_{\mathrm{m}}$ is a measure of the thermostability of DNA. The result of this study showed a significant reduction in the melting temperature of DNA due to exposure to dichlorvos. There is a possibility that continued exposure to dichlorvos may undermine the integrity of DNA of the poultry birds and this may have far reaching effects on future generations of the birds. There is a direct relationship between the GC (Guanine + Cytosine) content of a DNA sample and its melting temperature. DNAs with higher GC content have higher melting temperatures. Random amplified polymorphic DNA (RAPD) is a new method developed for the detection of genotoxicity of pollutants (Atienzar et al., 2002; Noel and Rath, 2006; Atienzar and Jha, 2006). Four out of the six primers used in the RAPD-PCR analysis generated different banding patterns in all the DNA samples tested. However only 3 primers, designated OPA-02 (5'-TGCCGAGCTG-3'), OPC-04 (5'CCGCATCTAC-3') and OPE-01(5'CCCAAGGTCC-3'), produced distinguishable banding profiles between the control DNA sample and those exposed to different concentrations of dichlorvos. The differences in banding profile came in the form of variations in band intensity, which was more pronounced in the RADP-PCR product amplified with OPE-01 primer where there is complete disappearance of DNA bands in the birds exposed to $0.04 \%$ pesticide contaminated feed. A number of reports have appeared on the usefulness of RAPD-PCR assay in the quick screening of exposed cells to pollutants (Becerril et al. 1999; Weinberg et al. 2001). Most of the results of DNA alterations detected by the RAPD technique were on in vitro studies. Till date, the ability of dichlorvos to cause DNA damage in vivo is still in question. Studies carried out on selected organophosphate pesticides revealed that organophosphates are genotoxic (Malhi and Grover, 1987). Lieberman et al., 1998) reported chromosomal damage in peripheral blood found in patients exposed to domestic application of organophosphates. Shadnia et al. (2005) also reported that chronic exposure to organophosphate pesticides was associated with increased DNA damage. Our study revealed that there were slight changes in the molecular pattern of DNA as a result of exposure to dichlorvos. These changes were more pronounced in the DNA samples from birds exposed to 0.02 and $0.04 \%$ dichlorvos where the bands were either faint or completely absent. Although, there has not been any previous report of genotoxicity by dichlorvos in vivo, results of our study suggest that with the use of the random amplified polymorphic DNA (RAPD) technique, it is possible to detect genotoxicity in animals after prolonged exposure to dichlorvos.

\section{CONCLUSION}

This study highlights the potentials of using DNA based analysis in evaluating the environmental impact of pesticide exposure. The study has shown that melting temperature as well as DNA profile on agarose gel can be used as biomarkers of pesticide (dichlorvos) exposure.

\section{ACKNOWLEDGEMENT}

We are grateful to the staff of Nigerian Institute of Medical Research (NIMR) for their technical support towards this project.

CONFLICT OF INTEREST: Authors have no conflict of interest.

\section{REFERENCES}

1) Atienzar, F.A. and Jha, A.N., 2006. The random amplified polymorphic DNA (RAPD) assay and related techniques applied to genotoxicity and carcinogenesis studies: a critical review. Mutation Research,: 613(2-3): 76-102.

2) Atienzar, F.A., Venier, P. and Jha, A.N., 2002. Depledge MN. Evaluation of the random amplified polymorphic DNA (RAPD) assay for the detection of DNA damage and mutations. Mutation Research, 52(1-2): 151-163.

3) Becerril, C., Ferrero, S.F.and Castano, A., 1999. Detection of mitomycin $\mathrm{C}$-induced genetic damage in fish cells by use of RAPD. Mutagenesis,: 14(5): 449- 456.

4) Birnboin, H.C. and Jevcak, J.J., 1981. Flourimetric method for Rapid detection of DNA strand breaks in human 
white blood cells produced by low doses of radiation. Cancer Research, 41: 1889-1892.

5) Bolognesi, C., Creus, A., Ostrosky-Wegman, P. and Marcos, R., 2011. Micronuclei and pesticide exposure. Mutagenesis, 26, 19-26.

6) Booth, E.D., Jones, E. and Elliott, B.M., 2007. Review of the in vitro and in vivo genotoxicity of dichlorvos, Regul Toxicol Pharmacol.: 49(3):316-326

7) Frank, R., Braun, H.E. and Clegg, B.S., 1990. Survey of farm wells for pesticides, Ontario, Canada, 1986 and 1987, Bull Environ Contam Toxicol, 44, 410-419.

8) Hazarika, R. and Das, M., 1998. Toxicological impact of $\mathrm{BHC}$ on the ovary of the airbreathing catfish Heteropneustes fossilis (Bloch), Bull Environ Contam Toxicol., $\quad$ 60:16-21.

9) John, P.J., 2007. Alteration of certain blood parameters of freshwater teleost Mystes viptatus after chronic exposure to Metasystox and Sevin. Fish Physiol Biochem., 33:15-20.

10) Lieberman, A.D., Craven, M.R., Lewis, H.A. and Nemenzo, J.H., 1998. Genotoxicity from domestic use of organophosphate pesticides. $J$ Occup Environ Med. 40(11):954-957.

11) Malhi, P.K. and Grover, I.S., 1987. Genotoxic effects of some organophosphorus pesticides. II. In vivo chromosomal aberration bioassay in bone marrow cells in rat. Mutat Res. 188(1):45-51.
12) Noel, S and Rath, S.K., 2006. Randomly amplified polymorphic DNA as a tool for genotoxicity: an assessment. Toxicology and Industrial Health, 22 (6): 267275.

13) Partanen, T., Mbakaya, C., Ohayo-Mitoko, G. and Ngowi, A.V.F., 1999. East Africa Pesticide Network: Progress, results and impact. Afr Newslett on Occup Health and Safety. 9: 4-5.

14) Sambrook, J., Fritsch, E.F. and Maratis, T., 1989. Molecular Cloning: A laboratory Manual. Cold Springs Harbor Laboratory Press, Cold Springs Harbor, New York, 450pp.

15) Santalucia, J., 1998. A united view of polymer dumbbell and oligonucleotide DNA nearest-neighbour thermodynamics. Proceedings National Academy of Science, 95(4): 14601465.

16) Shadnia, S., Azizi, E., Hosseini, R., Khoei, S., Fouladdel, S., Pajoumand, A., Jalali, N. and Abdollahi, M., 2005. Evaluation of oxidative stress and genetoxicity in organophosphorus insecticide formualators. Hum Exp Toxicol., 24(9): 439-445.

17) Weinberg, H.S., Korol, A.B. and Kirzhner, V.M., 2001. Very high mutation rate in offspring of Chenobyl accident liquidators, Proceedings of the Royal Society B, 268 (1471): 1001-1005.

18) Wolfe, H.R., Staiff, D.C. and Armstrong, J.F., 1973. Persistance of parathion in soil. Bull Env Contamn Toxicol., $10: 1-9$.

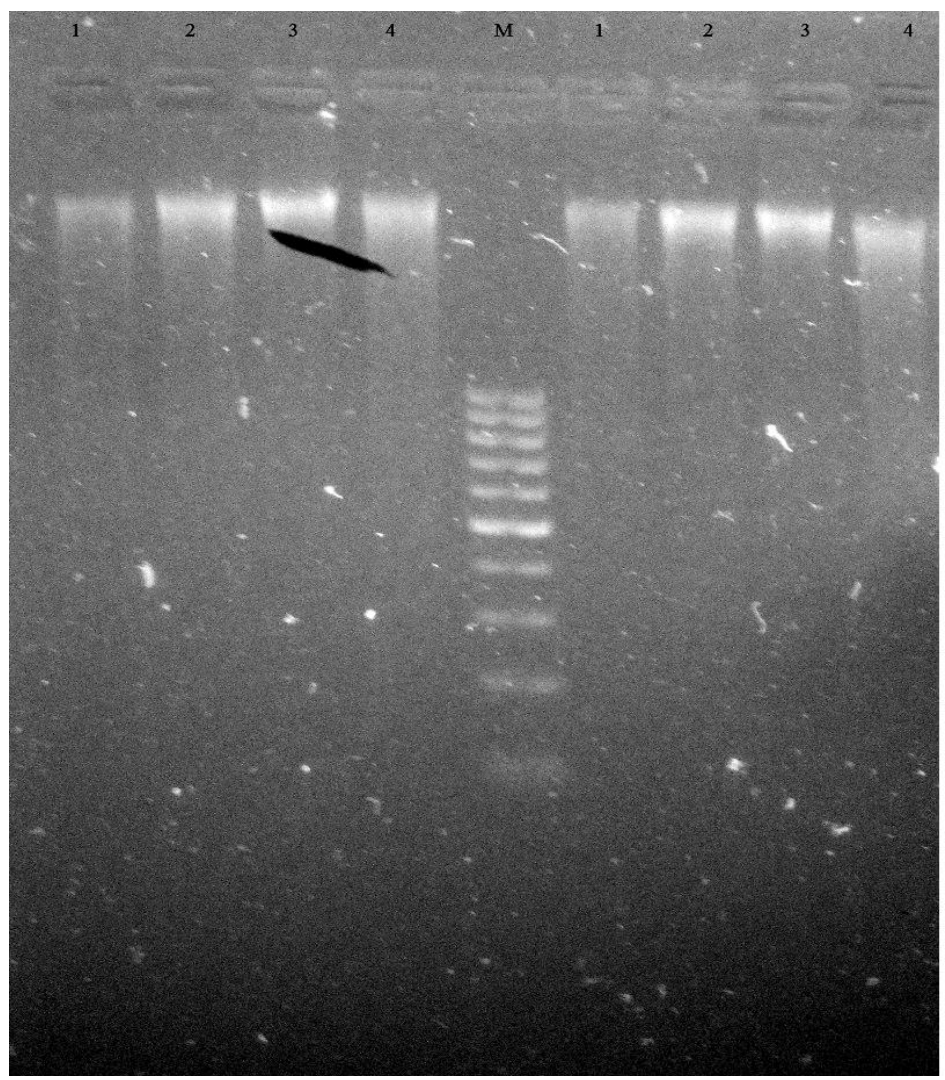

Plate 1: Agarose gel electrophoresis of liver DNA Samples. Lane $1=$ control, lane $2=0.01 \%$ DDVP, Lane $3=$ $0.02 \%$ DDVP, lane $4=0.04 \%$ DDVP, $\mathrm{M}=$ marker.

Table 1: Quantitation of DNA isolated from the liver of poultry birds exposed to DDVP 


\begin{tabular}{lll}
\hline Experimental Group & A260/280 & Yield (ng/UL) \\
\hline Control & $1.72 \pm 0.01$ & $2507.0 \pm 394.14$ \\
$0.01 \%$ DDVP & $1.67 \pm 0.05$ & $2417.5 \pm 138.16$ \\
$0.02 \%$ DDVP & $1.72 \pm 0.01$ & $3271.3 \pm 255.26$ \\
$0.04 \%$ DDVP & $1.75 \pm 0.04$ & $3978.1 \pm 149.34$ \\
\hline
\end{tabular}

Each sample was assayed twice for DNA quantitation at 260nm. Purity was determined based on A260/280 ratio.

Table 2: Summary of melting temperature, percentage nucleotide bases of liver DNA samples

\begin{tabular}{|c|c|c|c|c|c|c|c|}
\hline \multicolumn{2}{|c|}{ Experimental group } & \multirow[t]{2}{*}{$\mathrm{T}_{\mathrm{m}}\left({ }^{\circ} \mathrm{C}\right)$} & \multicolumn{2}{|l|}{$\% \mathrm{GC}$} & \multirow{2}{*}{$\frac{\% \mathrm{AT}}{56.5}$} & \multicolumn{2}{|r|}{ GC/AT ratio } \\
\hline Control & $87.2^{\mathrm{a}}$ & & 43.5 & & & & $0.77^{\mathrm{a}}$ \\
\hline $0.01 \%$ DDVP & & $82.1^{\mathrm{b}}$ & & 31.3 & & 68.7 & $0.46^{\mathrm{b}}$ \\
\hline $0.02 \%$ DDVP & & $82.0^{\mathrm{b}}$ & & 30.0 & & 70.0 & $0.43^{b}$ \\
\hline $0.04 \%$ DDVP & & $81.1^{\mathrm{b}}$ & & 27.8 & & 72.2 & $0.39^{\mathrm{b}}$ \\
\hline
\end{tabular}

Values expressed as standard error values \pm of the samples $(\mathrm{N}=3)$.

${ }^{a-b}$ Means within a column with no common superscript differ significantly at $\mathrm{p}<0.01$

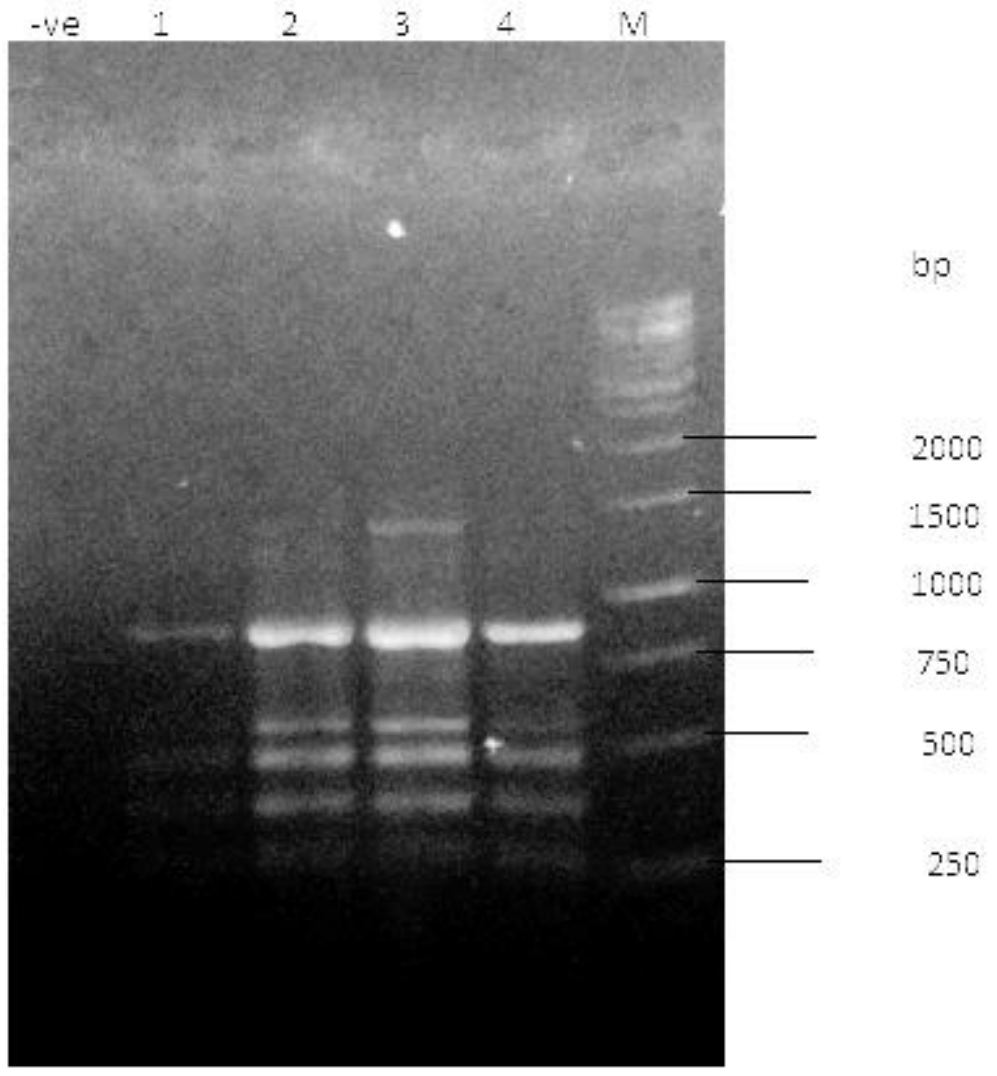

Plate 2. RAPD profile showing DNA pattern of liver of poultry birds exposed to $0.01 \%$ [2], $0.02 \%$ [3], and $0.04 \%$ [4] DDVP. The control [1] contained no pesticide. The primer used for amplification is OPA 02. 


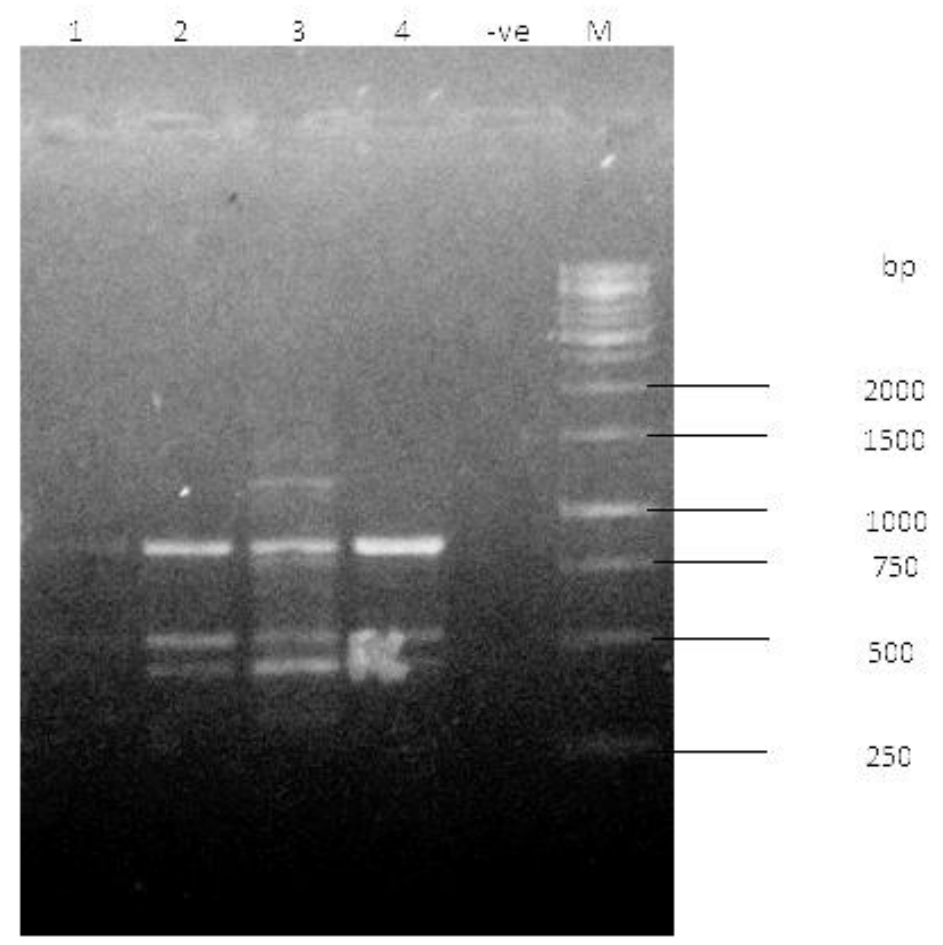

Plate 3. RAPD profile showing DNA pattern of liver of poultry birds exposed to $0.01 \%$ [2], $0.02 \%$ [3], and $0.04 \%$ [4] DDVP. The control [1] contained no pesticide. The primer used for amplification is OPC 04.

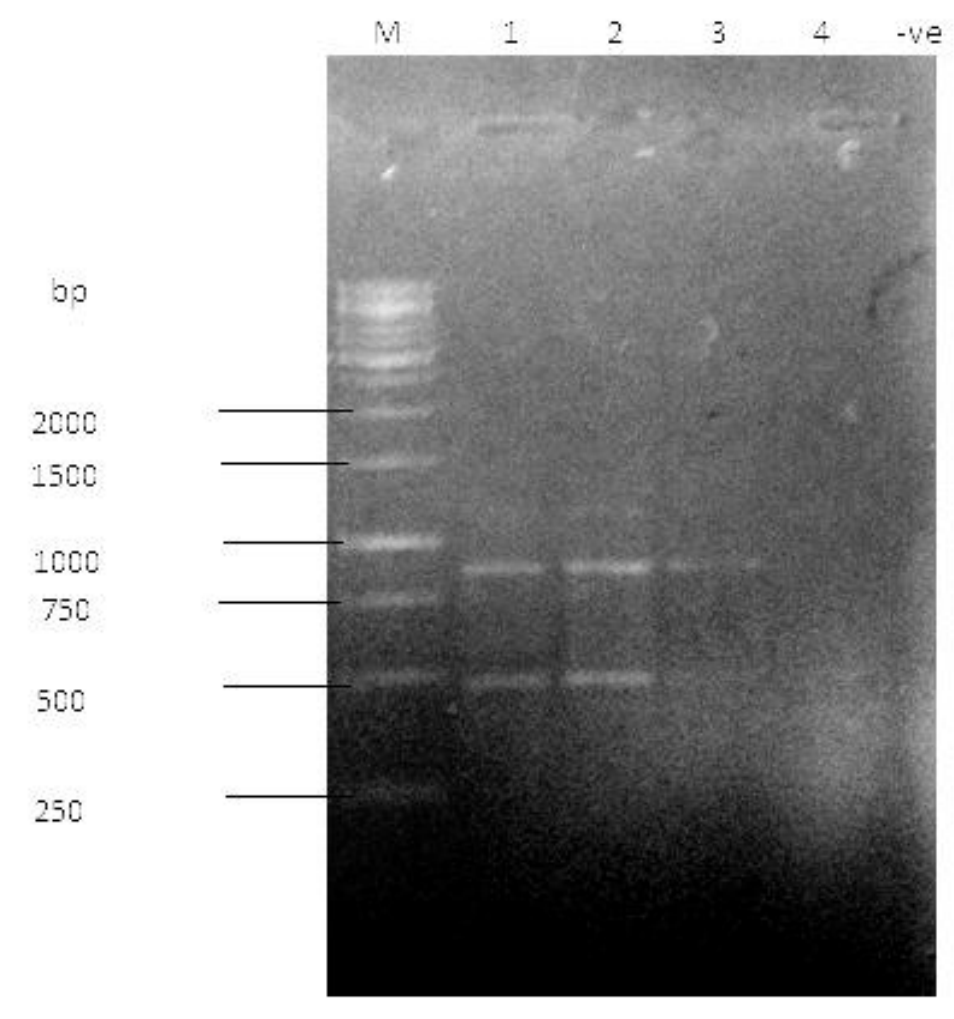

Plate 4: RAPD profile showing DNA pattern of liver of poultry birds exposed to $0.01 \%$ [2], $0.02 \%$ [3], and $0.04 \%$ [4] DDVP. The control [1] contained no pesticide. The primer used for amplification is OPE 01. 